\title{
The publication of memory - from the Via crucis to the terrorist memorial
}

\section{Göran Sonesson}

The notion of memory is ambiguous in multiple ways. It can be an event, an act of memory; or it can consist of a structure conserving and organizing a set of facts. In the first case, it may involve the automatic retention of the 'just evolved' moment in the stream of consciousness, or it can be a deliberate act with a purpose to build up, or to search, the space of recorded facts. In the second case, the information can be accumulated in the brain, as an endogram, or in an object independent of the body, as an artefact or an exogram. Elsewhere, I have suggested that the photograph, at least from the Instamatic to the selfie, partakes of several of these kinds of memory. The same could be said about the monument, although the latter necessarily involves a public dimension. Maurice Halbwachs and Alfred Schütz have written enlightening things about collective memory which are worth exploring. None of them, however, were able, at the time, to take into account the difference between two kinds of publication of memory: the official one, which is what first comes to mind, epitomized in war monuments or in the monuments of the Holocaust; and, on the other hand, the monuments erected on places where terrorist acts have occurred, which become public events only because of the concurrence of many individual acts of commemoration, which is not to say that they are not socially conditioned. The purpose of this paper is to elucidate the second kind of memorial publication.

Keywords Monument, Memory, Relevancies, Public Space, Consciousness

\section{Envoi}

If there is such a thing as the semiotics of monuments, we must start by inquiring into the way into which monuments convey meanings. As a first approach, it may seem that a 
monument must be an object located in a particular part of space, which invokes some event or series of events in the past, whether this was the original purpose of the object or not. It might already be concluded that the monument as a monument has to be situated in both time and space. Several glosses can be made to this characterization. In the historical sense of the term, a monument is erected on purpose, but recent experience of terrorist deeds, not to forget the ancient Via Crucis, shows that something may become a monument to an act that has occurred in that very space, without any object being originally dedicated to that purpose.

Moreover, a monument is traditionally expected to constitute a physical presence occupying some particular part of space; but the part of the monument which is physically present, and the part which is simply projected from memory or imagination is variable. Thus, a place where a terrorist act has occurred will no doubt at first be decorated with flowers and other objects. However, in the long run, these objects will disappear, and yet the place will continue to form a monument to those who remember the act. Something like that must have been true of the Via Crucis, during the Middle Ages, when itineraries to Jerusalem were published (see Sonesson 2019) - although it should not surprise me, if more recently, the itinerary has been marked out physically, as a service to the tourists.

A third complication is that a monument may be (physically) erected in a place in which the commemorated event did not take place, whether the monument was erected by official powers (such as the Estonia monument in Stockholm) or was a more spontaneous work, such as street art referring to some politically salient event having occurred in that country, which may, for various reasons, not appear in the place where the event took place.

If the monument has as physical presence, it may, or may not, contain signs, such as writing or pictures, but, as is particularly obvious in the case of terrorist acts, signs are not necessary for meaning to be there. Auschwitz is to us a monument to the Holocaust, although that was not why it was built; the Holocaust monument in Berlin was created especially to commemorate the Holocaust, although it is not situated in a spot singularized by specific events having to do with the Holocaust (which is not to deny that the Holocaust also happened in Berlin, though not, as far as I know, in the particular spot where the monument is located).

Finally, monuments in the narrow sense are erected in public places through a decision by some kind of public authority, but, in an extended sense, also the cross placed by family members close to the road where a person had a mortal traffic accident, or even the memorial to a dog created by someone in his garden may be considered a monument. It seems that our notion of monument is very much a prototype concept. However, as I pointed out long ago (without referring to this particular case; Sonesson 1989: 330ff), in polemics against Eleanor Rosch (et alia, 1976), this does not mean that there are not things which are clearly not monuments.

Where does this leave us? Whatever the problem with the first definition proposed above, the notion of monument fundamentally involves the notions of time and space. Therefore, it should not only be productive to scrutinize the temporal and spatial relations of monuments 
for their own sake, but such an exploration may turn out to be also rewarding for specifying the nature of semiosis generally. This is obviously true about the notion of sign, but it may also apply to the notions of public and less public spaces.

\section{The monument as a temporal object}

The primary sense in which the monument is a temporal object is, of course, the same in which everything offered to perception is such. It is part of the experience of a perceiving subject in the here and now. There are, however, less trivial ways in which the monument is temporally anchored. The nature of memory changes with the type of semiotic resources in which it is embodied. Certain types of memory are implicit in the very body of human beings and other animals; others are clearly distinct artefacts, such as knots on handkerchiefs and photographs; others consist of storehouses of facts accessible to the intersubjective knowledge of generations and generations of ever greater numbers of human beings. The interactions of semiosis and memory are complex, and we are still far from understanding all the complexities of this interrelation.

\section{Temporality in the stream of consciousness}

At least one contemporary neuroscientist, Gerald Edelman (1992), whose professional access to the mind is quite different in nature to mine, nevertheless recognizes the existence of 'Jamesean properties', such as intentionality, which are irreducible characteristics of human consciousness. William James (1978 [1890]: I, 179-182) is, of course, particularly famous for having introduced the idea of a 'stream of consciousness' or, as he also says, 'of thought,' in which the 'specious present' is surrounded by 'fringes' that extend to both past and future. As Aron Gurwitsch (1957) has shown, James's conception of the stream of consciousness is very similar to the way Edmund Husserl (1966 [1928]) conceives temporal consciousness, as consisting, in James' (1978 [1890]: 279) terms, of temporal parts which envisage the same object in different ways and which melt into each other in a continues stream. Husserl, however, would appear to be more meticulous in his description, specifying that every present moment already includes references to the past (retentions), which include references to even earlier moments, and so on (retentions of retentions, etc.) and references to the future (protentions), with references to even later times, etc. (protentions of protentions, etc. see Fig. 1a), which means that each protension flows into another, and so on, as the retentions do, and there will be retentions of protensions and protensions of retentions in addition to that. Retentions and protensions can also give rise to a sort of accumulation of meaning, in the sense of Lotman, or more precisely, of a sedimentation of meaning, as Husserl (1939) understood it: a superimposition of meaning on the temporal process. 


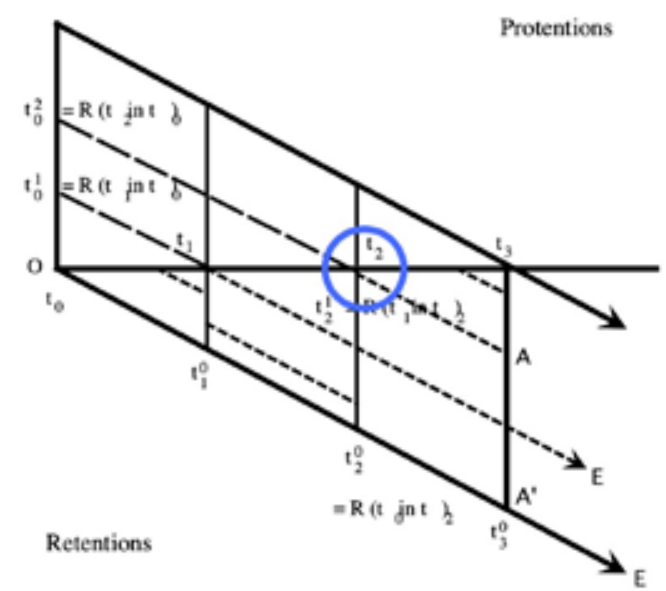

a

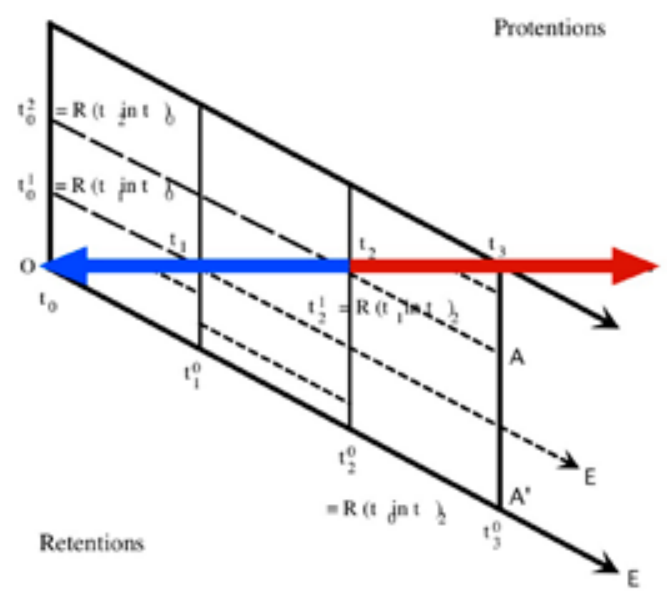

b

Figure 1: The temporal consciousness according to Husserl (1966 [1928]), extended in both temporal directions by Sonesson (1999b): a) Retentions and protensions; b) acts of anticipation and remembering.

According to Merlin Donald (1991: 149), monkeys live entirely within the limits of episodic memory, which he takes to mean that they spend their entire life living in the present, consisting in a series of concrete episodes. To live entirely in the present may seem like a simple condition, but if it implies an awareness of the insertion of the present into the past and the future, it is already a complex capacity. Indeed, this would require what Husserl calls retentions (of the past) and protentions (of the future). It is very different to live in the present, without understanding it as an opposition to the past and the future, as one would expect the case to be for the tick, as its existence (its Umwelt) is described by Jakob von Uexküll (1983 [1934]). Donald is undoubtedly aware of this, as he attributes such an episodic memory only to monkeys, human beings and human predecessors. But one could expect there also to be a pre-episodic stage. I have argued that to live in the present knowing that it is the present is to live in the current of consciousness with its retentions and its protentions; but living in the present without being able to appreciate its difference from the future or the past is an even simpler condition that seems to characterize the tick among many other animals (see Sonesson 2006; 2015).

At one level, the Umwelt of the tick is structured by time, since the three acts that form its life according to von Uexküll must be performed in a certain order. In the beginning, the tick is suspended motionless on a branch until it perceives the odour of butyric acid emitted by the cutaneous glands of a mammal, causing it to fall from the branch where it is posed. When coming into contact with the mammal's warm body, the tick perambulates on the body of its host in order to find the least hairy part of the skin, allowing it to start drinking the blood of its host. 
Thus, the Umwelt of the tick is provided with a temporal structure according to McTaggart's $\mathrm{B}$-series, that is to say, it is divided into a before and an after, but it does not require anything like the division of the stream of consciousness, in terms of past, present, and future, which characterize McTaggart A-series (see Gell 1992: 149ff.). To move from Series B to Series A, you need to insert an Ego into the time series, for which there is a lapse of time both before and after the situation in which it is currently located.

Thus, retentions and protections are clearly distinct from acts of memory and anticipation, which are active events in their own right. As Husserl $(1966,1928)$ points out, protentions and retentions are parts of a complete act and should not be confused with separate acts of memory and anticipation (see Fig. 1b). It would therefore seem that it is not enough (but it is certainly necessary) to have a current of consciousness in order to be able to "travel in time", in the sense of Endel Tulving (1983), that is to say, to place oneself imaginatively in time before or after the present moment. This is what Tulving calls 'episodic memory'. Diana monkeys use different warning signals to communicate the presence of different classes of predators, such as a leopard, an eagle or a snake. Klaus Zuberbühler et al. (1999) demonstrated that the monkeys were more upset (giving more repeated calls) when, five minutes after listening to the alarm call corresponding to an eagle, they heard the roar of a leopard instead of the scream of an eagle. This shows that the monkeys have kept in memory the meaning of the alarm call they had heard before. However, to do this, it is not necessary to resort to time travel, or, in different terms, to realize a specific act of memory, but only to have a current of consciousness in the sense of McTaggart's A-series.

In a well-known study of what they qualified as 'episodic-like memory', Clayton and Dickinson (1998) showed that white-throated scrub jays remember where they collected food, as well as the nature of the food kept in their different caches. It seems undeniable that this requires a journey back in time, that is, an independent act of memory, even if the procedure appears to be limited to a domain of special interest to the animal, food resources, and even if we cannot know whether the animals have any feeling of time-travelling (see Clayton et al. 2007). It has also been found that chimpanzees are able to collect stones to use the next day to throw at tourists who come to watch them at the zoo, and that chimpanzees and orangutans are able to pick the right tool necessary for a task they know will be set for them afterwards (Osvath 2009, Osvath \& Osvath 2008). These are certainly active anticipatory acts, which seem to involve also some acts of memory, and they are not so immediately directed towards the procuration of food as in the case of scrub jays (although in the second case, they may be so indirectly). Thus, time travel, in the sense Tulving understands the term, seems to be present also among other animals and goes well beyond the experience of the current of consciousness.

To erect and experience monuments, you certainly need episodic consciousness in Tulving's sense, since you must be able to travel in time. The foregoing analysis of temporal objects should therefore offer some clues to understanding the semiotic status of monuments, as used 
by human beings. In the narrow sense of the term, a monument clearly requires there to have been a specific act of remembering an event, which was the impetus for creating some kind of physical object located at a specific place. In a wider sense of the term, no specific physical object is necessary, except for the environment prompting an act of remembrance of a sequence of earlier experienced protentions and retentions, in particular if the latter is culturally shared (part of collective memory, in the sense of Halbwachs (1950 [1925]; see further below). In reality, moments often partake of several of these semiotic operations. Thus, for example, Auschwitz is a monument to the Holocaust for everybody who has been an inmate of the concentration camp, but also, in a different way, to all of us who have heard about it in history lessons or in the media. The Auschwitz victim only has to bring back, through a personal act of memory, his or her stream of consciousness at the time of detention. The rest of us (fortunately) need to have recourse to segments of collective memory which we project onto the site. Quite another thing is that national or international authorities may officially proclaim the site to be a monument and then perhaps erect a physical object, or at least append a signboard stating the fact. Such a procedure requires an active act of remembrance, customarily conveyed by a sign. Such an officially proclaimed act of remembrance may however also be applied to a place which is not particularly associated with streams of consciousness occurring at the time at that very spot, as in the case of the Berlin Holocaust monument.

\section{Temporality as sedimentation}

According to Jurij Lotman (1976), the accumulation of information as well as of goods (by which we must understand material objects) precedes their exchange and constitutes a more elementary and fundamental characteristic of a culture than the latter. Material objects and information, Lotman claims, are similar to each other and differ from other phenomena in two ways: They can be accumulated, whereas, for example, sleep and breathing cannot be accumulated, and they are not completely absorbed into the body, unlike food, but remain separate objects also after the reception. A lot could be said about this analogy, its advantages and its perils, and we have done so elsewhere (see Sonesson 1999a, 2010, 2015). In the present context, it will be sufficient to retain two elements of this critique. First, if accumulation means integration into predefined structures, the accumulation of information is very different from the accumulation of material objects. Far from being a stack of objects, the accumulation of meaning is an intentional process, in the double sense of a process that is about something else and that is present for someone. Insofar as it involves the integration of elements into a pre-existing structure carrying meaning, accumulation in Lotman's sense could be identified with sedimentation, in Husserl's sense, namely the process by means of which previous acts are conserved in a passive form, which not only can be reanimated, but which also give rise to interpretative schemes which can be used as a basis for the understanding of subsequent acts. 
The latter point is explicitly made by Alfred Schütz (1974 [1932]). However, this idea becomes more interesting if (as suggested by Sonesson 2018) we can identify these schemes of interpretation with what Schütz (1970) later was to call the systems of relevancies, which are social in nature, and the function of which is to guide our interest in given situations as they occur in the Lifeworld. This again may be considered a kind of collective memory, in the sense of Maurice Halbwachs (1952 [1925]; 1950; see Sonesson 2018), to the extent that such systems of relevancies are shared between members of a group or a society. Language, and most other semiotic systems, thus form part of collective memory.

In the second place, even the most elusive type of information must be 'embodied' in some kind of material substance, in order to be accessible in time and space. This can happen in at least two very different ways. It may have its primary existence in the mind, either in an individual mind, or being intersubjectively shared by some group, thus forming a kind of collective memory, but it also needs to be materially manifested in some way. In the case of dead languages, for example, their continuing existence depends on writings which have been preserved; languages which are still spoken, however, and other semiotic systems still current, every day produce numerous material manifestations of their existence.

In the present context, nevertheless, it is the second case which is of particular interest. This is the sense in which Merlin Donald (2010) talked about exograms, as vehicles for conserving memory external to the mind, comparable in that respect to the endograms in the brain. Examples would be those devices we know as books, pictures, records, CDs, hard disks, and so on. Indeed, as I have explained elsewhere (Sonesson 2019), the photograph is a particularly interesting kind of exogram which embodies all sorts of temporal connections. Some kinds of 'extended mind', in the sense nowadays current in cognitive science, also would seem to involve exograms in Donald's sense. Andy Clark \& David Chalmers (1998) tell a story about Otto and Inga, who both go to a museum. Otto has Alzheimer's disease, which is the reason why he has written down all the directions to the museum in a notebook to serve as his memory. Inga, however, is able to remember the directions using only her (un-extended) mind. The argument is that the only difference existing in these two cases is that Inga's memory is being internally processed by the brain, while Otto's memory is being served by the notebook. In other words, Otto's mind has been extended to include the notebook as the source of his memory. The notebook qualifies as such because it is constantly and immediately accessible to Otto, and it is automatically endorsed by him. At least according to the interpretation of Daniel Hutto \& Erik Myin (2013), this story suggests that, thanks to the notebook, Otto does not have to have any capacity for processing meaning in his own mind. In fact, however, if Otto cannot read, which is a semiotic act (that is, an act of extracting meaning), he cannot be doing anything at all with the notebook. The notebook is meaningless, if not actualized by a mind, just like writing in some unknown script for which no key has been found, as was the case, for instance, of the Maya script until recently (see Coe 1992). 
While an exogram needs to be material, it also has to possess a part of meaning. It requires some kind of indirect intentionality, both because it has to be produced by someone (as in the case of the camera placed on the finishing line of a horse race, which automatically takes a snapshot when the horses cross the line, but which must have been set up and armed with this intention by a subject, as explained in Sonesson 2002) and it has to be understood by someone (as in Otto's case). It is true that computer disks and CDs have to be 'read' by a computer and a CD-player, respectively, but even this is of no avail if there is nobody around to read the text or listen to the music. Thus, exograms require both a physical and an intentional presence.

The monument is certainly an exogram, or a piece of extended mind, in this sense. In the narrow sense of the term, a monument no doubt needs to be both material and mind-dependent. In some other sense, however, as we shall see, monuments can do with a little less materiality, but never with an absence of meaning.

\section{The monument as a spatial object}

In many ways, the monument may be conceived as a typical exogram, or as a manifestation of extended mind. In relation to memory, in the various senses we have identified, the monument shares many properties with other exograms, but it differs from them for at least two reasons. First, it is part of public space, whose meaning is at least partially defined by the collective memory of a particular group (a neighbourhood, a society, humanity, etc.). Secondly, it is located in a circumscribed physical space, which implies that it is accessible, in a sense, to all the people being in that place, and that it constitutes, at least marginally, a mandatory experience for all the people who pass by it. But there are many avatars of this spatial specificity which still remain to be explored.

\section{The monument as an object rooted in space}

In its most familiar shape, as epitomized by the bronze kings and other heroes looming large in most cities, the monument undoubtedly is a physical object, which is situated in physical space, sometimes relying on a physical connection to some event in the life of the real person it impersonates. In the city in which I live, Malmö, there is a statue, at the main square, of the Swedish king Charles $X$ Gustav. It is not clear whether the statue was erected here to remind us all that this king, more than 300 years ago, conquered for Sweden this part of what was at the time Denmark, as has sometimes been suggested; or whether the statue was erected here a little more than hundred years ago, simply as a specimen of the stripe of 'Swedish kings'. In the former case, the statue is clearly materially anchored in the humus of Malmö City. In the second case, the spatial relation is fuzzier. Nevertheless, it is still within the 
border of present-day Sweden, which is not true of other statues of the same king in Finnish Turku, as well as in Germany and Estonia, no doubt because these countries, or parts of them, were earlier Swedish colonies, and also in Minnesota, clearly because it was a centre of Swedish immigration to the US.

A more clear-cut case is constituted by the statue of the footballer Zlatan Ibrahimović very recently erected in his hometown, Malmö, and more specifically, not in the suburb, Rosengård, where he grew up and no doubt started out as a footballer, but in front of Malmö Stadion, where he must no doubt have spent some part of his early career. It is interesting that, at the beginning, the plan was to erect this statue outside the Friends' Arena in Stockholm, which would have rendered his statue as lost in space just like that of Charles X Gustav, according to the second interpretation suggested above.

While there may be no particular reason for the statue of Charles $X$ Gustav being situated at the main square of Malmö, some monuments are clearly placed on particular sites, although these are not the sites where the events commemorated took place. This would seem to be true of the Holocaust monument in Berlin, which was no doubt placed in Berlin, because it is the capital of Germany, and because it also was so at the time of the Holocaust, which means that it is placed in a kind of official shop window. ${ }^{1}$

Yet, in this location, the monument only carries meaning because we all know the story of the Holocaust, and we are aware of its numerous real sites. The monument erected in Stockholm to the victims of the MS Estonia disaster is also displaced in relation to the real event. It certainly could not be placed where the real catastrophe took place, in the middle of the Baltic Sea, for obvious material reasons. Since the ship was crossing the sea between Tallinn and Stockholm,

the choice of placing the monument in Stockholm was not arbitrary, but the showcase principle may still have played a part. More importantly, in both cases, the monument only makes sense to those who know the story, in the first case because of the history books, and in the second case thanks the news reports. But this introduces us to the case in which the narrative is primary, and the spatial attachment is entirely dependent on the story being told.

\section{The monument as an object projected onto space}

To the people of the Middle Ages, the most important moments were undoubtedly those in Jerusalem, those testifying to the sacred history of Christendom, especially the places by which Jesus was supposed to have passed the day of his condemnation and crucifixion. Seen in this light, there was a whole sequel of monuments in 'the Holy City', connected by a trajectory which had to be followed, although not much remained of these sites at the time. Numerous guidebooks were therefore written to help those who wanted to follow the monumental road, the first of which that is known to us is that of the 'pilgrim of Bordeaux': 
Leaving the rampart of Sion, and going towards the gate of Neapolis, there are walls on the right, a little further down the valley: this is the site of the house and the courtroom of Pilate. This is the place where the Lord was questioned before he was led away to his suffering. On the left is the small eminence of Golgotha, where the lord was crucified. A stone's throw away is found the cave where the Lord's body was laid at rest and from where he resurrected on the third day. It was there that, at the order of the Emperor Constantine, a basilica was recently erected, that is to say a church of admirable beauty (Marval 2002 [1996]: 32; my translation).

Commenting on such guidebooks, Maurice Halbwachs ([1941] 2008: 126) wrote:

Apart from its sacred character, the place of worship is a part of the ground whose position in space is defined. Like everything that is material, this position tends to remain what it is. / --- / It is from the day when a cult is organized, from the day when this place becomes a rallying point of a whole group of believers, that it becomes a holy place / ... /.

When reading Halbwachs, one cannot help wondering whether it is the materiality of the space that defines collective memory, or if, on the contrary, collective memory assigns a meaning to the ground. Perhaps Halbwachs is claiming that both processes take place concurrently, but there clearly are cases when one of them predominates. It is almost impossible to avoid (although Halbwachs managed to do so) associating such a notion of collective memory with the so-called 'art of memory', practised since antiquity and current during the Middle Ages, which was used, for instance, by rhetoricians, to memorize long lists of ordered elements, by projecting them onto already well-known places (Yates 1966, Carruthers 2008; Le Goff 1988: 146). One retains the structure of the space perceived (or easily pictured in the imagination) but fills the different slots with new material. Again, one may consider Kevin Lynch's notion of 'the image of the city' as an application of this idea: Lynch (1960) set out to investigate 'the visual quality of the American city by studying the mental representation of this city among its inhabitants' by focusing on such elements as paths, edges, districts, nodes, and landmarks. If we apply this analysis to the description offered by the pilgrim of Bordeaux, we see that he starts out passing a gate, which is a kind of node, while at the same time testifying to the existence of a path. He sees the walls, that is, edges, down in the valley, and then he visits a series of landmarks, which are at the same time monuments: the house of Pilate, Golgotha, the cave burial, and so on (For more details of these parallels, see Sonesson 2019).

The question then becomes: How much of these meanings is embodied securely in physical space (necessarily as given to the interpretation of a human, or otherwhere animate, being) - and how much is projected onto space from the system of relevancies harboured by the his- 
torical subjects visiting the place? The description given by the pilgrim of Bordeaux certainly suggests that most of the information has to be projected from the experiencing subject onto space. It may seem, nevertheless, that there must be some spatial detail which is really 'physically' there, though perhaps not a complete structure, contrary to what is required in the art of memory, and which has to be temporally connected to some event which took place at this very spot at some earlier moment.

Terrorist acts, mostly propagated by Islamic activists, of which Europe has seen a significant number in the new century, often result in monuments with only a rudimentary rootedness in space. They are attached to a place by a set of artefacts left on the spot in the aftermath of the event by individuals, who may be family members of the victims or other sympathetic people. These artefacts can be flowers, candles, toys etc. It is thanks to their accumulation that they constitute the monument. This happened in the cases of Sweden's two acts of Islamic terrorism, both taking place on and around Drottninggatan in central Stockholm. The first terrorist was Taimour Abdulwahab al-Abdal, who, in 2010, detonated his bomb too soon, killing only himself; the second terrorist was Rakhmat Akilov, who, in April 2017, drove a car along Drottninggatan killing five people and injuring a large number of others. However, the artefacts piled up at the spot of the event do not carry any meaning to people who are not familiar with the event, that is, who are not bearers of a version of sedimented temporal consciousness, either derived from their own experience on the spot at the time of the event, or more probably conveyed by news media. With time, these artefacts will probably be whisked away. The flowers, in any case, need to be replaced quite often if the monument should last. In fact, one cannot help wondering whether such assemblages of artefacts are agglomerated in places where terrorist acts are not singular occurrences standing out from the ordinary, but almost everyday events, such as, for instance, in Afghanistan. If not, the narrative becomes imperative.

There clearly are monuments which are not positioned at the very place where the event commemorated occurred. In this case, the story is all important. Such monuments are, of course, often officially sanctioned objects, such as the Berlin Holocaust monument and the Stockholm Estonia monument, where the narrative is emphasized by the use of writing, pictures or other signs. If the creation of the monument does not carry any official sanction, as may be the case with, for instance, street art, the entire burden of 'monumentship' has to be carried by signs and by systems of relevancies.

These cases allow us to discern clearly that a monument has a double object, on the one hand, a material reality, a figure, a place in space, and, on the other hand, a meaning which, in the mind of a group, is attached to and superimposed on that reality. Suppose, as Halbwachs (2008 [1941]) does, that the group splits, and some of its members remain on the spot, in the presence of the material object, in contact with it, while others move away from it, carrying with them the memory of the object. At the same time, the object changes. The very place it occupies does not remain the same, since around it everything is transformed. It no longer 
has the same relationship with the material world that surrounds it. In the example studied by Halbwachs, this is what happened to the Way of the Cross. It will certainly also happen to the commemorations of terrorist acts.

\section{The monument as a sign}

Here we will only briefly consider the question whether the monument is a sign or not. That depends, of course, on what is meant by monument (and we have seen that this very much depends on circumstances), and what is meant by (something being a) sign. It is a curious fact that semiotics has generally been unable to spell out a useful definition of the notion of sign. Elsewhere, taking my inspiration from both Husserl and Piaget, and in an effort to amplify their intuitions, I have suggested that the sign can be minimally defined by the following properties (see Sonesson 1989, 2006, 2012, 2016): (1) it contains (a least) two parts (expression and content) and is as a whole relatively independent of that for which it stands (the referent); (2) these parts are differentiated, from the point of view of the subjects involved in the semiotic process (the addresser and the addressee, or, as we will see, sometimes only the latter), even though the parts may not be objectively differentiated, that is, not separate instances of experience in the common sense Lifeworld (except as signs forming part of that Lifeworld); (3) there is a double asymmetry between the two parts, because one part, expression, is more directly experienced than the other; (4) and because the other part, content, is more in focus than the other; and (5) the sign itself is subjectively differentiated from the referent, and the referent is more indirectly known than any part of the sign.

In this sense, obviously, any monument containing writing, pictures, or anything of the kind, contains signs. And any object conventionally considered to be a monument will, by this very fact, be a sign. Still, this is not the whole story. The Berlin Holocaust monument is a sign for the Holocaust because we are told so. It is certainly a sign, a symbolic sign, in Peirce's sense, and more specifically a conventional sign. On the other hand, you can enter the monument, you can go move along its different parts (although there may not be any guidebooks comparable to those specifying the Via Crucis), you can touch its different parts, and you will certainly have an experience of meaning, but it is not, so far, a meaning of the kind carried by signs. Rather, it has to do with what James Gibson (1980) called affordances: the direct perceptual meaning resulting from experiencing the movement of your own body on a surface, touching other surfaces, etc. These meanings may well be said to be iconic, that is, motivated, not exactly by similarity, but rather by identity. However, to the extent that these experiences are meant to be related to some properties of the event commemorated by the Holocaust monument, this can only be determined conventionally by means of the story, yet not the story of the Holocaust, but of the story of the Holocaust monument. 


\section{The monument in public space}

The statue of the Swedish king Charles X Gustav erected in the central square of Malmö City, as well as those tokens of the same type found in Turku, in Germany and in Estonia, were no doubt the result of decisions taken by the relevant authorities, and this may also be the case, though perhaps not by means of the same procedure, of the one in Minnesota. This is also true of the statue dedicated to the footballer Zlatan Ibrahimović in his hometown Malmö. They are all, in slightly different ways, the result of public acts.

When Jürgen Habermas $(1962 ; 1989 ; 1992)$ introduced the notion of 'the bourgeois public sphere', where a dialogue could exist between different stakeholders, he contrasted it with what he called 'the representative public sphere', which he took to precede it, and which he clearly conceived as a space in which those in power were in the business of conveying to the people at large what they wanted them to think and believe in. In the ensuing discussion, a lot of other 'public spheres', such as a plebeian, a proletarian, and a feminist, public sphere, were proposed. But while these public spheres, if they exist, are historically and sociologically different from Habermas' 'bourgeois public sphere', they all seem to be conceived as involving discussion, rather than the imposition from above of the right kind of thinking. It therefore seems necessary to dissociate historical facts from structure. As observed by Sonesson \& Sandin (2016: 218ffs), Habermas' 'bourgeois public sphere', and all its competitors, all embody a spectacular function that is symmetrical and intermittent (see Sonesson 2000), whereas Habermas' 'representative public sphere', involves an asymmetric and enduring spectacular function, similar to that at the theatre, but, of course, with more power behind the scenes. Structurally, it would therefore make more sense to distinguish between an interactional public sphere and a presentative public sphere, without imposing historical limits on them. Here we are essentially concerned with the latter.

Physically, of course, all monuments are in the public sphere, that is, they are erected in spaces open to, and customarily frequented by, the public. In the narrow sense of the term, moreover, monuments, as they have been characterized above, are manifestations of the presentative public sphere: their existence is imposed 'from above', by public authorities. When flowers, crosses, photographs and other objects are brought together on the side of the public road, to indicate that a traffic accident has occurred on this very spot, the decision to create the monument is clearly private, although the result of the act is offered to the public. In such cases, the narrative is mostly held privately, and we, as a public, are only able to understand that a traffic accident occurred to somebody to us unknown close to this spot. Although usually referring to more publicly shared events, street art is also private in this sense, even if it is not necessarily created by one individual, but possibly by a group deprived of official authority. In Sonesson (2019s), I discussed this distinction in the terms proposed by Michel de Certeau (1980), opposing strategies, the initiative for which is taken by official bodies, and tactics, at- 
tributed to individuals or groups without any official sanction. Monuments in the narrow sense are the results of strategies, in the sense of de Certeau, which are the result of decisions taken within institutions and structures of power. According to de Certeau, tactics, on the other hand, are actions which overturn the strategies by means of an ingenious way of using them. The problem with this terminology, however, is that it brings the meaning of the terms very far from that of ordinary language. The advantage of the terminology, nevertheless, is that it may help us realize that there are acts which partake of both strategies and tactics, in de Certeau's sense.

The monument to terrorist acts is a case in point. Monuments to terrorist acts will normally appear in public spaces, in fact, at the centre of central places of the country, because these are the places where terrorist acts tend to occur (in Europe, not, for instance, in Afghanistan, where targets are chosen using other criteria). There is normally not, at least at the beginning, a decision by any official body to create a monument on the spot where the terrorist act was executed (though this may happen later, as in the case of the Twin Towers). Still, it would be wrong to think of these monuments as being created at the initiative of individuals or oppositional groups, overturning, more or less ingeniously, as de Certeau suggests, the rules imposed by the powers that be. It is, of course possible that at some stage (but hardly the next day), people who were present at the event, but who survived, may return to the spot and leave some memorandum. But the creation of the monument is no doubt due to all those people who were not present, but who got to know about the event through the media and felt the need to vent their sentiments by means of some kind of physical token. Since, on such occasions, multitudes of people may feel the same need, it can hardly be denied that there is an element of social conformism in such a behaviour, whether or not there is some real empathy involved. Thanks to the media, we nowadays are faced with acts of collective memorialization that Maurice Halbwachs could not have dreamt of.

Acts of vandalism applied to statues seem to be closer to the meaning given by de Certeau to the notion of tactics. In fact, such acts could be considered tactics applied to strategies, and thus, at least minimally, as creating a kind of interactional public space. Ever since the statue of Charles X Gustav was erected on the Malmö central square in 1896, there has been a continuing criticism, voiced in newspaper articles, involving the convenience of placing a statue of the Swedish king who conquered this former part of Denmark and incorporated into Sweden in the city centre of Malmö. Nevertheless, as far as I have been able to ascertain, it has never been the subject of any publicised acts of vandalism (though I have seen objects used to delimit places of roadwork being placed on the king's head). The case of the Zlatan statue is different. The statue was inaugurated in October 2019, but it was repeatedly vandalized already in November, after it was revealed that Zlatan had invested part of his considerable fortune in a competing football club.

One such act of vandalism consisted in hanging a toilet lid on his neck. This is certainly a 
case of tactics, in de Certeau's sense, and even an instance of the interactional public sphere. It is a pity, however, that it involved such a petty argument.

\section{Conclusion}

In the narrow sense of the term, the monument seems to be rather clearly circumscribed: It is a physical object, situated in a space which is culturally defined as being public, being erected at the initiative of some official authority, and which refers to some event in the past (including a life span). We have seen that not all monuments have to fulfil all criteria (and we may not have explored all the alternatives: for instance, could a monument refer to the future or the present, instead of the past?). Nevertheless, in an attempt to generalize, we will suggest that the monument is always a meaning more or less rooted in space and referring to a different moment in time, and which is offered to public experience. Even though monuments may not be signs or contain signs, given a stricter strict definition of the latter term, they do seem to comply with the idea of signs as notae, first conceived by, among others, Hobbes and Leibniz (see Dascal 1978): the proverbial knot on the handkerchief, publicly exposed.

\section{NOTES}

1 In the sense of Section 5 below, some public spaces are more public than others.

\section{REFERENCES}

Carruthers, Mary 1990. The book of memory: a study of memory in medieval culture. Cambridge: Cambridge Univ. Press.

Certeau, Michel de 1980. L'invention du quotidien. 1, Arts de faire, Union générale d'éditions Clark, Andy \& Chalmers, David 1998. The extended mind. Analysis 58 (1): 7-19.

Clayton, Nicola, \& Dickinson, Anthony 1998. Episodic-like memory during cache recovery by scrub jays. Nature 395 (6699): 272-274.

Clayton, Nicola, Salwiczek, Lucie, \& Dickinson, Anthony 2007. Episodic memory. Current Biology, 17: 6. DOI: https://doi.org/10.1016/j.cub.2007.01.011

Coe, Michael 1992. Breaking the Maya code. London: Thames and Hudson.

Dascal, Mario 1978. La sémiologie de Leibniz. Montaigne.

Donald, Merlin 1991. Origins of the Modern Mind. Cambridge, Mass.: Harvard University Press.

Donald, Merlin 2010. The Exographic Revolution: Neuropsychological Sequelae. In: The Cog- 
nitive Life of Things: Recasting the Boundaries of the Mind, edited by Lambros Malafouris and Colin Renfrew. Cambridge: McDonald Institute for Archaeological Research, 71-79.

Edelman, Gerard 1991. Bright Air, Brilliant Fire. On the Matter of the Mind. London: Penguin Books. Gibson, James 1980. A prefatory essay on the perception of surfaces versus the perception of markings on a surface, in The perception of pictures, Volume I: Alberti's window. Hagen, Margaret (ed.), xi-xvii. New York: Academic Press.

Gurwitsch, Aron 1957. Théorie du champ de la conscience. Bruges : Desclée de Brouver.

Habermas, Jürgen 1962. Strukturwandel der Öffentlichkeit. Berlin: Luchterhand.

Habermas, Jürgen 1989. The public sphere: An encyclopedia article. In: S. E. Bronner \& D. Kellner (Eds.). Critical theory and society: A reader. New York: Routledge.

Habermas, Jürgen 1992. Further reflections on the public sphere. In: C. Calhoun (Ed.), Habermas and the public sphere. Cambridge, MA: MIT press.

Halbwachs, Maurice 2015 [1928]. La psychologie collective. Paris: Flammarion.

Halbwachs, Maurice 2008 [1941]. La topographie légendaire des évangiles en Terre Sainte. Paris: PUF.

Halbwachs, Maurice 1952 [1925] Les cadres sociaux de la mémoire: Paris: PUF.

Halbwachs, Maurice 1950. La mémoire collective. Paris: PUF

Husserl, Edmund 1966 [1928]. Zur Phänomenologie des inneren Zeitbewusstseins. Den Haag: Nijhoff.

Husserl, Edmund 1939. Erfahrung und Urteil. Prag: Academia Verlagsbuchhandlung.

Hutto, Daniel \& Myin, Erik 2013. Radicalizing enactivism: basic minds without content. Cambridge, Mass.: MIT Press.

James, William 1078 [1950]. The principles of psychology. Vol. 1-2. New York: Dover Publications.

Gell, Alfred 1992. The anthropology of time: cultural constructions of temporal maps and images. Oxford: Berg.

Le Goff, Jacques 1988. Histoire et mémoire. Paris: Gallimard.

Lotman, Jurij 1976. Culture and information, Dispositio. Revista hispánica de semiótica literaria, 3(1): 213-215.

Lynch, Kevin 1960. The image of the city. Technology Press, Cambridge, Mass.

Maraval, Pierre (ed.) 2002 [1996]. Récits des premiers pèlerins chrétiens au Proche-Orient [IVeVIle siècle]. Paris: Les Éditions du Cerf.

Osvath, Matthias 2009. Spontaneous planning for future stone throwing by a male chimpanzee. Current biology 19, R190-191.

Osvath, Matthias \& Osvath, Helena 2008. Chimpanzee-Pan troglodytes-and orangutan-Pongo abelii -forethought: self-control and pre-experience in the face of future tool use. Animal cognition 11, 661-674

Rosch, Eleanor, Mervis, Carolyn B., Gray, Wayne D., Johnson, David M. \& Boyes-Braem, Penny 1976. Basic objects in natural categories. Cognitive Psychology 8(3): 382-439. 
Schütz, Alfred 1974 [1932]. Der sinnhafte Aufbau der sozialen Welt: eine Einleitung in die verstehende Soziologie. Frankfurt am Main: Suhrkamp.

Schütz, Alfred 1962-1996. Collected papers 1-4. The Hague: Martinus Nijhoff.

Schütz, Alfred 1970. Reflections on the problem of relevance. New Haven: Yale University Press. Sonesson, Göran 1989. Pictorial concepts. Lund : Lund University Press.

Sonesson, Göran 1999a. The signs of life in society-and out if. Sign System Studies 27: 88-127.

Sonesson, Göran 1999b. Postphotography and beyond. From mechanical reproduction to digital production, VISIO 4(1): 11-36.

Sonesson, Göran 2000. Action becoming art: "Performance" in the context of theatre, play, ritual - and life. VISIO 5(3): 105-122.

Sonesson, Göran 2002. The act of interpretation. A view from semiotics. Galáxia, 4, 67-99. Sâo Paolo, EDUC.

Sonesson, Göran 2006 . The meaning of meaning in biology and cognitive science. A semiotic reconstruction. Sign Systems Studies 34(1): 135-214.

Sonesson, Göran 2010. Semiosis and the elusive final interpretant of understanding. Semiotica 179(1): 145-258.

Sonesson, Göran 2012. The foundation of cognitive semiotics in the phenomenology of signs and meanings, Intellectica, 58: 207-239.

Sonesson, Göran 2015. From Remembering to Memory by Way of Culture. A Study in Cognitive Semiotics. Southern Journal of Semiotics - Special issue: 'Memory as a Representational Phenomenon'. 5(1): 25-52.

Sonesson, Göran 2016. Lifeworlds: The Cognitive Semiotics of Culture. In David Dunér, \& Göran Sonesson (eds). Human Lifeworlds: The Cognitive Semiotics of Cultural Evolution. Frankfurt/M.: Peter Lang, 23-62.

Sonesson, Göran 2018. New Reflections on the Problem(s) of Relevance. In: Relevance and Irrelevance: Theories, Factors and Challenges. Hisashi Nasu \& Jan Straßheim (eds.), 21-50. Berlin: de Gruyter.

Sonesson, Göran 2019. Pour une rhétorique des lieux de mémoire. In: Monuments, (de)monumentalisation: approaches sémiotiques. Bayaert-Geslin, Anne, Chatenet, Loduvic, \& OKala, Françoise (eds), 37-55. Limoges: PULIM.

Sonesson, Göran \& Sandin, Gunnar 2015. Urbanity: The City as the Specifically Human Niche. In: Dunér, David, \& Sonesson, Göran (eds.), 191-228. Human Lifeworlds: The Cognitive Semiotics of Cultural Evolution. Frankfurt/M.: Peter Lang.

Tulving, Endel 1983. Elements of episodic memory. Oxford: Clarendon.

von Uexküll, Jakob 1983[1934]. Streifzüge durch die Umwelten von Tieren und Menschen: ein Bilderbuch unsichtbarer Welten, Frankfurt am Main: S. Fischer.

Yates, Frances 1978 [1969]. The art of memory, Harmondsworth, Penguin. 
28 The publication of memory - from the Via crucis to the terrorist memorial

Zuberbühler, Klaus, Cheney, Dorothy L., \& Seyfarth, Robert M. 1999. Conceptual semantics in a nonhuman primate. Journal of Comparative Psychology 113(1): 33-42.

Göran Sonesson is Professor at the Department of Cognitive Semiotics, Lund University Sweden.

Email: Goran.sonesson@semiotik.lu.se 